\title{
A gyermekkori tehéntejfehérje-allergia diagnosztikai kihívásai
}

\author{
Lendvai-Emmert Dominika ${ }^{1}$ - Emmert Vanessza dr. ${ }^{2}$ \\ Fusz Katalin dr. ${ }^{3}$ - Prémusz Viktória ${ }^{1}$ - Németh Viktória dr. ${ }^{4}$ \\ Ligetvári Roland $^{1}$. Tóth Gergely Péter dr. ${ }^{2}$ \\ ${ }^{1}$ Pécsi Tudományegyetem, Egészségtudományi Doktori Iskola, Pécs \\ ${ }^{2}$ Soproni Erzsébet Oktató Kórház és Rehabilitációs Intézet, Csecsemő- és gyermekosztály, Sopron \\ ${ }^{3}$ Pécsi Tudományegyetem, Általános Orvostudományi Kar, Élettani Intézet, Pécs \\ ${ }^{4}$ Pécsi Tudományegyetem, Klinikai Központ, Bőr-, Nemikórtani és Onkodermatológiai Klinika
}

Bevezetés és célkitüzés: Kisgyermekek körében a leggyakrabban előforduló ételallergia a tehéntejfehérje-allergia, melynek klinikai megnyilvánulása igen változatos; emiatt a betegség diagnosztizálása sok esetben kihívást jelent, ami a korrekt diagnózis késői felállításához vezethet. Humánrészvizsgálatunk célja az allergia fennállásának kimutatására szolgáló diagnosztikai módszerek vizsgálata, valamint a betegséggel összefüggő viselkedésbeli problémák objektív paraméterekkel való alátámasztása.

Módszer: Vizsgálatunkba tehéntejfehérje-allergia gyanúját felvető tünetekkel érkező gyermekeket vontunk be (n = 47). A kutatásban részt vevő gyermekektől nyál- és vérmintát vettünk, valamint saját szerkesztésű kérdőívet (a DSM5 figyelemhiányos hiperaktivitási zavarra vonatkozó tünetlistáját is tartalmazza) töltettünk ki a szülőkkel. A klinikumban az allergia kimutatásának egyik leggyakoribb diagnosztikai módszere a Prick-teszt, mely esetünkben 47 (n = 47, átlagéletkor: 7,36 év) gyermekből 2-nél adott tejre pozitív eredményt. A gyakorlatban leginkább gyógyszerallergia kimutatására használt lymphocytatranszformációs teszt 8 gyermeknél pozitív, további 4-nél kétes eredményt mutatott. A pszichés eltéréseket vizsgáló részkutatásunkban $(\mathrm{n}=43$, átlagéletkor: 7,88 év, ) a figyelemhiányos hiperaktivitási zavar tünetlistája alapján a kapott pontok a diéta előtti értékhez képest $(6,88$, SD: 4,43) szignifikáns csökkenést mutattak 3 hónap eliminációs diétát követően $(4,48, S D: 3,69, p=0,001)$. Az alvászavart panaszként említők figyelemhiányra/hiperaktivitásra vonatkozó pontjainál (10,62, SD: 4,23) szignifikáns csökkenést tapasztaltunk a diétát követően $(6,69, \mathrm{SD}: 4,59, \mathrm{p}=0,009)$. A nyálkortizolszintek tekintetében a diéta előtti és utáni értékekben nem tapasztaltunk szignifikáns eltérést.

Eredmények: Elmondhatjuk, hogy önmagában a Prick- és a lymphocytatranszformációs teszt nem alkalmas a tehéntejfehérje-allergia fennállásának kimutatására. Tapasztalataink azt mutatják, hogy a tejfehérje indukálta figyelemzavar, fokozott impulzivitás, illetve alvászavar tekintetében az eliminációs diéta a tünetek mérsékeltebb előfordulását vagy akár teljes megszűnését eredményezi.

Következtetés: Vizsgálataink eredményeinek tükrében elmondhatjuk, hogy a klinikai tünetekben látványos javulás csak a szigorúan betartott diéta mellett várható.

Orv Hetil. 2019; 160(33): 1311-1318.

Kulcsszavak: tehéntejfehérje-allergia, Prick-teszt, lymphocytatranszformációs teszt, kortizol, figyelemhiányos hiperaktív rendellenesség

\section{Diagnostic challenges in pediatric cow's milk protein allergy}

Introduction and aim: The aim of our research is to evaluate and compare commonly performed diagnostic tests, and to examine the psychological disorders induced by this food allergy. Children with symptoms suggesting cow's milk protein allergy were included in this study $(n=47)$. Blood and saliva samples were collected from the participants. Parents were asked to fill in a questionnaire constructed by the research team (containing the DSM-5 symptoms checklist about attention deficit hyperactivity disorder).

Method: One of the most widely used diagnostic tool is the skin allergy test, which was performed in 47 subjects ( $\mathrm{n}=47$, mean age: 7.36 years); only 2 children showed positive test result for cow's milk. Lymphocyte transformation test was observed to be positive in 8 children (17\%), 4 subjects demonstrated questionable results. In our substudy about psychological symptoms ( $n=43$, mean age: 7.88 years), the score was according to the attention deficit hyperactivity disorder symptom checklist before the diet (6.88, SD: 4.43) and showed significant decrease after 3 
months of the elimination diet $(4.48, \mathrm{SD}: 3.69, \mathrm{p}=0.001)$. Scores of children with sleep disorder $(10.62, \mathrm{SD}: 4.23)$ also represented a significant reduction after 3 months of the diet $(6.69$, SD: $4.59, p=0.009)$. Salivary cortisol levels did not show significant changes before and after elimination diet.

Results: According to our data, skin allergy testing and lymphocyte transformation test are not reliable diagnostic tools for establishing the diagnosis.

Conclusion: We conclude that a significant improvement in clinical symptoms can only be achieved with a strict elimination diet.

Keywords: cow's milk protein allergy, skin allergy test, lymphocyte transformation, cortisol, attention deficit hyperactivity disorder

Lendvai-Emmert D, Emmert V, Fusz K, Prémusz V, Németh V, Ligetvári R, Tóth GP. [Diagnostic challenges in pediatric cow's milk protein allergy]. Orv Hetil. 2019; 160(33): 1311-1318.

(Beérkezett: 2019. február 22.; elfogadva: 2019. április 3.)

\begin{abstract}
Rövidítések
ACTH $=$ adrenokortikotrop hormon; ADHD = (attention deficit hyperactivity disorder) figyelemhiányos hiperaktivitási zavar; $\mathrm{CRH}=$ (corticotropin-releasing hormone) kortikotropinfelszabadító hormon; DSM-5 = (Diagnostic and statistical manual of mental disorders) Mentális rendellenességek kórmeghatározó és statisztikai kézikönyve; EDTA = (etilén-diamin-tetraecetsav; ELISA $=$ (enzyme-linked immunosorbent assay) enzimhez kapcsolt immunszorbens-vizsgálat; FBS = (fetal bovine serum) magzati borjúvérszérum; $\operatorname{IgE}=$ immunglobulin-E; LTT = lymphocytatranszformációs teszt; MAKIT = Magyar Allergológiai Klinikai Immunológiai Társaság; $\mathrm{MTT}=$ Tiazolkék-tetrazolium-bromid; RPMI= Roswell Park Memorial Institute-féle tápfolyadék; SD = standard deviáció
\end{abstract}

A tehéntej-allergia a tehéntejfehérjére adott hiperszenzitivitási reakció, mely többféle klinikai formában jelenhet meg. Megkülönböztetünk IgE-mediált, nem IgE-mediált és kevert formákat, melyek egymásba átalakulhatnak [1]. Az entitás prevalenciája csecsemőkorban $2-6 \%$, elöfordulásának gyakorisága az életkor előrehaladásával csökken, de bármely életkorban kialakulhat [2-6]. A tehéntej-allergia prognózisa jónak mondható, Polgár szerint a csecsemőkori tehéntejfehérje-allergiában szenvedők esetében l éves korra 15\%-uknál, 3 éves korra 51\%-uknál, 4 éves korra 67\%-uknál várható gyógyulás [3]. Ezzel szemben Høst az eliminációs diéta bevezetésétôl számítva vizsgálta a gyógyulás időtartamát, miszerint a betegek $45-50 \%$-a gyógyul meg l év tejfehérjementes diétát követően; az eliminációs diéta bevezetését követően gyógyulás figyelhető meg 2 év után 60-75\%-uknál, míg a 3. évben 85-90\%-uknál [6]. Klinikailag a leggyakrabban gastrointestinalis, bőr- és légúti tünetek, valamint viselkedésbeli eltérések formájában jelentkezhet az allergia.

A kórkép diagnózisában a klinikai tünetek mellett a széklet-okkultvérzés kimutatása, a szérum-IgE-szintmeghatározás, késóbbi életkorban a nutritív Prick-teszt a leggyakrabban alkalmazott vizsgálati módszerek; ritkáb- ban lymphocytatranszformációs tesztet végeznek az allergia kimutatására [7].

A klinikai gyakorlatban a fenti tesztek negatív eredménye esetén sok esetben elvetik a táplálékallergia diagnózisát. Fontos azonban megjegyezni, hogy a táplálékterheléssel összehasonlítva a Prick-tesztnek és a specifikus IgE-vizsgálatnak a specifitása és a pozitív prediktív értéke alacsony, szenzitivitásuk és negatív perdiktív értékük azonban magas [8], valamint hogy a lymphocytatranszformációs teszt az IgE-mediált táplálékallergia fennállásának bizonyítására nem javasolt [9], így önmagukban elvégezve a diagnózis felállításához történő alkalmazásuk nem célszerü $[8,10,11]$.

A tehéntejfehérje-allergia egyik leggyakoribb manifesztációja az allergiás colitis, melynek következményei a hasfájás, a - gyakran véres - hasmenés, puffadás, hányás. A tehéntejfehérje-mentes diéta bevezetésével ezen tünetek viszonylag gyorsan regrediálnak, ez azonban nem objektív mutatója az allergiás colitis gyógyulásának. A gastrointestinalis érintettség diagnosztikai lehetőségeit vizsgáló részkutatás eredményeire jelen közleményünk nem tér ki.

Tehéntejfehérje-allergiás gyermekek esetében gyakran megfigyelhető, hogy a szervi eltérések mellett magatartásbeli problémák is jelentkeznek: a szülők gyakran figyelemzavarról, fokozott impulzivitásról, alvászavarról számolnak be, melyek biológiai háttere pontosan nem ismert. ADHD-s (attention deficit hyperactivity disorder) gyermekek esetében több tanulmány alátámasztja a tehéntejfehérje-mentes diéta jótékony hatását [12-14]; fordított összefüggésben azonban, miszerint a tehéntejfehérje-allergiás gyermekek magatartászavara a diéta bevezetése után jelentôs javulást mutat, egyelöre nem áll rendelkezésre átfogó vizsgálat. A viselkedésbeli probléma biológiai háttere, illetve a tejfehérje kóroki szerepe nem tisztázott; legjobb tudomásunk szerint jelenleg nem lelhető fel olyan tanulmány az irodalomban, amely ezen összefüggést vizsgálja. Hipotézisünk szerint a CRH-ACTH-kortizol tengely, illetve az allergiás folyamatokban jelen lévő mediátorok, mint például a szeroto- 
nin és a hisztamin, szerepet játszhatnak a hiperaktivitás, a koncentrációs nehézségek és az alvászavar kialakulásának patomechanizmusában.

Humánkutatásunk célja a gyermekkori tejfehérje-allergia által indukált komplex élettani és pszichológiai folyamatok pontosabb megértése. A mérések és a kérdőívek kiértékelésének segítségével szeretnénk felmérni, hogy milyen organikus és esetlegesen pszichés eltérések jelentkeznek tejfehérje-allergiában, és ezekre milyen hatással van a tejfehérjementes diéta bevezetése. A betegség több aspektusára kiterjedő, átfogó vizsgálat lebonyolítását tervezzük. A hosszabb távú vizsgálat célja, hogy megfigyelhessük, a tejfehérjementes diéta jótékony hatása hogyan monitorozható objektív paraméterek segítségével.

\section{Módszer}

\section{Minta}

Kutatásunk kvantitatív, longitudinális típusú. A mintagyưjtés 2017. február és 2017. december között, a Tolna Megyei Balassa János Kórház gyermekgasztroenterológiai szakrendelésén zajlott. A vizsgált populáció 1-18 éves, tehéntejfehérje-allergia gyanúját felvető tünetekkel rendelkező csecsemők, gyermekek, serdülők csoportja.

A betegkiválasztás módja nem véletlenszerú, célirányos, szakértői mintaválasztás volt. A vizsgálatban való részvételhez szóbeli és írásos tájékoztatást követően, beleegyező nyilatkozatot tettek a gyermekek szülei/törvényes képviselői; a részvétel teljesen önkéntes volt, és a vizsgálatot indoklás nélkül bármikor megszakíthatta a vizsgálatban részt vevő gyermek vagy a szülő/törvényes képviselő. Az adatok kezelése és tárolása anonim módon történt. A diagnózis felállításához az 1. ábra szerinti diagnosztikai algoritmust vettük alapul $[3,15]$.

A mintagyújtés két szakaszban történt, azonban a vizsgálatba bevont gyermekek három alkalommal jelentek meg a szakrendelésen. Az első alkalommal a tejfehérje-allergiára utaló panaszokkal érkező betegek megjelentek a gasztroenterológiai szakrendelésen, ahol a kutatásban részt vevő gyermekek szülei/törvényes képviselői a vizsgálat, illetve a mintavételezés menetéről pontos szóbeli és írásbeli tájékoztatást kaptak. Ezen megjelenéskor nutritív Prick-teszt, valamint LTT elvégzése céljából vérvétel történt, emellett a diéta megkezdése előtt nyálmintákat gyưjtöttünk. Egy hónap szigorú eliminációs diétát követően kértük a szülőktől, hogy terheljék vissza tejfehérje-tartalmú élelmiszerrel gyermeküket, és kérdőívben kérdeztünk rá tapasztalataikra [3]. Amennyiben a diétát követő állapotjavulást a visszaterhelés kapcsán a tünetek ismételt jelentkezése követte, ezzel nagy valószínûséggel alátámasztva a tehéntejfehérje-allergia fennállását, úgy a gyermek a kutatásba bevonásra került. 3 hónap szigorú tejfehérjementes diéta tartását követően a fenti biológiai minták ismételt levétele történt, amivel célunk az eliminációs diéta hatékonyságának követése volt objektív paraméterek segítségével.

A vizsgálatba bevont 55 gyermek közül 8 (14,5\%) nem teljesítette a feltételeket, így ők nem vehettek részt a kutatásban. A kizárás okai: hiányosan kitöltött kérdőív és a biológiai minták hiánya vagy nem megfelelő menynyisége $(\mathrm{n}=4 ; 7,3 \%)$; az egy hónapos eliminációs diéta, majd a tejfehérjével való visszaterhelés során nem igazolódott az allergia $(\mathrm{n}=1 ; 1,8 \%)$; a kutatásban való részvétel önkéntes visszamondása $(\mathrm{n}=3 ; 5,5 \%)$. A teljes mintából $(\mathrm{n}=47)$ a viselkedésbeli eltéréseket vizsgáló

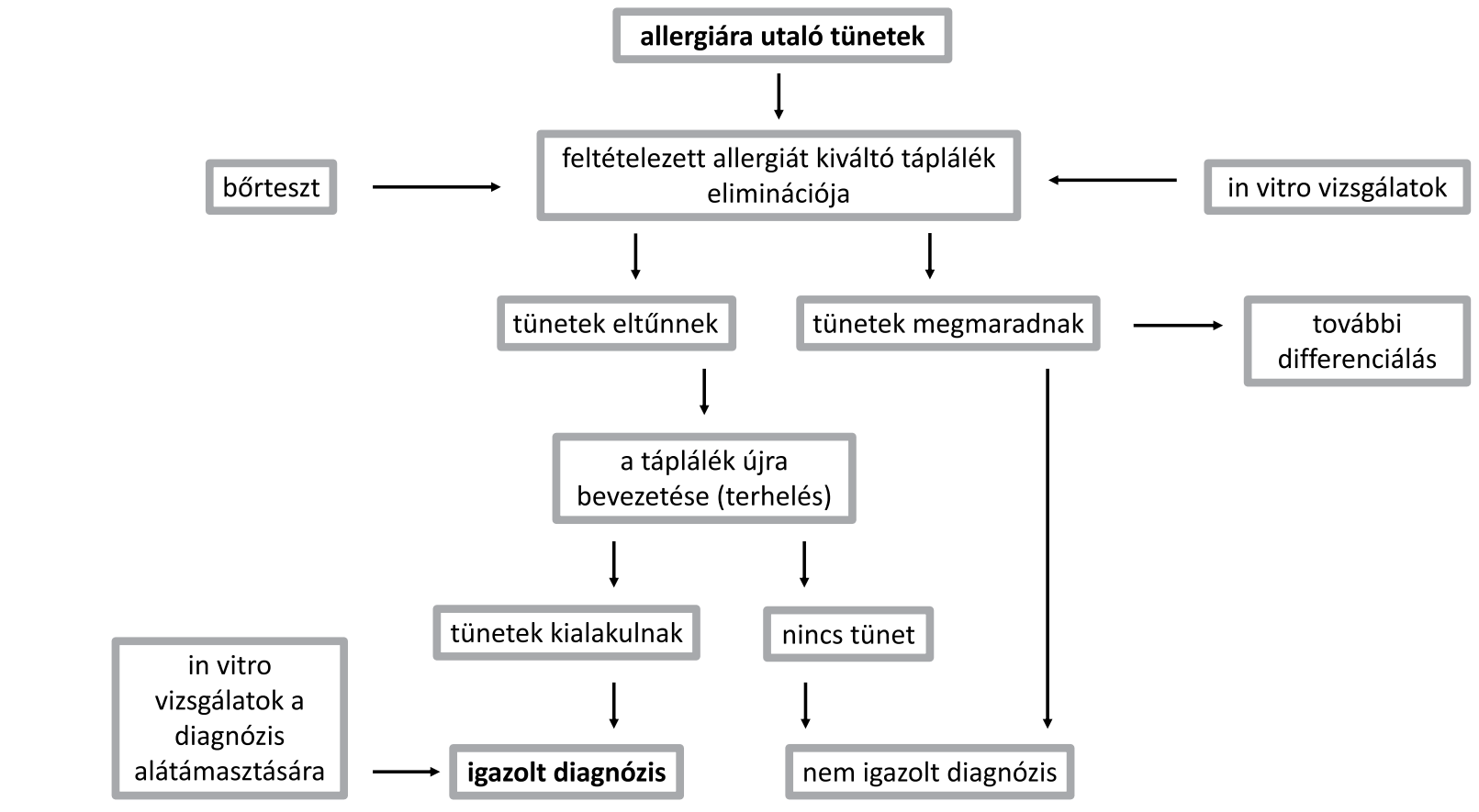

1. ábra

| Diagnosztikai algoritmus a táplálékallergia igazolására 
részkutatásunkból további $4(8,5 \%)$ kisgyermeket zártunk ki, mert velük kapcsolatban a DSM-5 szerinti ADHD-tünetlista alapján összeállított kérdőív nem volt alkalmazható (3 év alattiak voltak, vagy nem jártak még közösségbe). További kizárási kritériumként gyulladásos bélbetegség (Crohn-betegség, colitis ulcerosa), illetve coeliakia fennállását jelöltük meg.

\section{Prick-teszt}

A Prick-teszt („alkaros bőrpróba”) egy gyors és egyszerü mód különböző allergénekre adott túlérzékenységi reakciók diagnosztizálására. Leginkább az 1 . típusú ( $\mathrm{IgE}$ mediált) allergiás reakciók, fóleg a légúti allergének kimutatására alkalmas módszer, de táplálékallergia fennállásának gyanúja esetén is az első diagnosztikai módszerek között szerepel. Az alkar hajlítófelszínére, a csuklótól és a könyökhajlattól legalább 2-3-cm-re cseppentettük a nutritív allergén-kivonatokat (negatív és pozitív kontrollal együtt), majd a cseppek alatti bőrfelszínt Prick-lándzsával megsértettük, ezáltal az allergén a mélyebb hámrétegekbe is bejutott. A vizsgált bőrfelületet 15 perc elteltével ellenőriztük. Amennyiben az allergiás göb átmérője meghaladta a $3 \mathrm{~mm}-\mathrm{t}$, az eredményt pozitívnak értékeltük [16].

\section{Lymphocytatranszformációs teszt}

A lymphocytatranszformációs teszt (LTT) elsősorban gyógyszerallergiák kimutatására szolgáló in vitro eljárás, de táplálékallergiák diagnosztikájában is alkalmazható $[2,3,7]$. A betegtől nyert alvadásgátolt (citrát, heparin vagy EDTA) vérmintából, sưrüséggradiens centrifugálás útján mononukleáris sejtek izolálhatók, melyeket a vizsgálni kívánt allergén jelenlétében - esetünkben kereskedelmi forgalomban kapható tehéntej $10 \times$-es és $100 \times$-os hígításában - standardizált körülmények között $\left(37^{\circ} \mathrm{C}\right.$, $5 \% \mathrm{CO}_{2}, 72$ óra) sejtkultúrában tenyésztenek (RPMI 1640, 10\% FBS, 1\% L-glutamin, 1\% antibiotikum/antimycoticum). Az allergénspecifikus szenzitizáción átesett betegek mintáiban az allergént felismerő lymphocyták klonális proliferációja történik. Ennek mértéke az inkubációs idő leteltével, a mintához adott tiazolilkéktetrazolium-bromid (MTT) segítségével határozható meg. A módszer a keletkezett színreakción keresztül megmutatja a stimulált életképes lymphocyták metabolikus aktiválódásakor végbemenő oxidoredukciós folyamatok összességét. A sejtek osztódási rátájának meghatározása kontroll-, stimulálatlan tenyészethez viszonyítva történik.

\section{Nyálmintavétel}

A nyálminták gyưjtése a betegek otthonában, meghatározott időpontokban és módszerekkel történt, melyek a következők: a reggeli nyálminta gyưjtése ébredést köve- tően azonnal, a száj tiszta vízzel történő öblítését követően 2-3 perccel, az esti minta levétele 18:00 és 20:00 óra között történt, előre feliratozott, 1,5 ml-es Eppendorfcsövekbe. A mintavétel előtt minimum 30 perccel az étkezés, a folyadékfogyasztás, a dohányzás, a rágógumihasználat és a testmozgás kerülését kértük. A mintavételt követően a nyálmintákat hütőben, $2-8{ }^{\circ} \mathrm{C}$-on tároltuk maximum 72 órán keresztül, ezt követően a mintákat 5 perc időtartamú, 3000 rpm fordulatszámú centrifugálással készítettük elő további vizsgálatra. A kortizolszint meghatározásáig a mintákat $-20{ }^{\circ} \mathrm{C}$-on tároltuk [17].

\section{A kortizolszint meghatározása}

A korábban előkészített nyálmintákból ELISA-módszerrel határoztuk meg a kutatásban részt vevők nyálkortizolszintjét. A méréshez a NovaTec Immundiagnostica GmbH (Dietzenbach, Németország) ELISA-kitjét használtuk. A nyálmintákat duplikátumban vittük fel a platere $(25 \mu \mathrm{l} /$ lyuk $)$. Az intraassay variációs koefficiens $\leq 10 \%$, az interassay variációs koefficiens $\leq 8,3 \%$ volt.

A mérés során kapott mennyiségek mértékegységét (ng/ml) átváltottuk (nmol/l) az 1. táblázat alapján [1820].

1. táblázat | Kortizolátváltási formulák

\begin{tabular}{lll}
\hline Kapott mértékegység & Átváltási faktor & $\begin{array}{l}\text { Átkonvertált } \\
\text { mértékegység }\end{array}$ \\
\hline $\mathrm{nmol} / 1$ & $\times 0,03625$ & $\mu \mathrm{gg} / \mathrm{dl}$ \\
$\mathrm{ng} / \mathrm{ml}$ & $\times 0,276$ & $\mathrm{nmol} / 1$ \\
$\mu \mathrm{g} / \mathrm{dl}$ & $\times 27,6$ & $\mathrm{nmol} / 1$ \\
\hline
\end{tabular}

\section{A kérdöivek kiértékelése}

A saját szerkesztésû kérdőívek szociodemográfiai, az egészségmagatartással, egészségi állapottal, valamint a születési körülményekkel kapcsolatos kérdéseket tartalmaztak, ezenfelül a viselkedésre vonatkozóan a DSM-5 [21] ADHD-tünetlistáját is magában foglalta.

\section{Statisztikai analizis}

A statisztikai módszereket a MS Excel 2007 (Microsoft Corporation, Redmond, WA, Amerikai Egyesült Államok [USA]) és az SPSS 20.0 (IBM Corporation, Armonk, NY, USA) programokkal végeztük: leíró statisztika, egymintás- és kétmintás t-próba, ANOVA, lineáris regresszió. Az eredményeket $\mathrm{p}<0,05$ esetén tekintettük szignifikánsnak.

\section{Etikai szempontok}

A kutatás protokoll szerinti elvégzését a Tolna Megyei Önkormányzat Balassa János Kórházának Intézeti Kutatásetikai Bizottsága a 2017. 02. 22-i ülésén engedélyez- 
te, majd a regionális engedélyt a Pécsi Tudományegyetem Klinikai Központjának Regionális és Intézményi Kutatásetikai Bizottságától 2017. 06. 09-én kaptuk meg (ügyiratszám: 6750). A dolgozat nem sérti a helsinki deklaráció elő́rásait.

\section{Eredmények}

\section{Szociodemográfiai és klinikai adatok}

Vizsgálatunkban összesen 47 gyermek vett részt (2. táblázat). A nemek aránya közel azonos, 27 fiú és 20 lány volt a vizsgált gyermekek között. A vizsgált populáció nagy részét óvodás- $(31,9 \%)$ és kisiskoláskorúak $(40,4 \%)$ alkották, kisebb részben kisded- $(8,5 \%)$, prepubertás$(8,5 \%)$ és pubertáskorcsoportba sorolt gyerekek (10,6\%). A vizsgált gyermekek közel 50\%-ánál fordult elő a testvé-

\section{2. táblázat |A vizsgált gyermekek demográfiai és klinikai adatai}

\begin{tabular}{|c|c|}
\hline Változók & $\begin{array}{l}\text { A vizsgálatban } \\
\text { részt vevook, } \\
\text { n (\%) }\end{array}$ \\
\hline \multicolumn{2}{|l|}{ Nem } \\
\hline Fiú & $27(57,4 \%)$ \\
\hline Lány & $20(42,6 \%)$ \\
\hline \multicolumn{2}{|l|}{ Korcsoport } \\
\hline Kisded (1-3 év) & $4(8,5 \%)$ \\
\hline Óvodás (<3-6 év) & $15(31,9 \%)$ \\
\hline Kisiskolás (<6-11 év) & $19(40,4 \%)$ \\
\hline Prepubertás (12-14 év) & $4(8,5 \%)$ \\
\hline Pubertás (<14-18 év) & $5(10,6 \%)$ \\
\hline \multicolumn{2}{|l|}{ Családi anamnézis } \\
\hline Atopiás vagy gyulladásos bélbeteg anya & $11(23,4 \%)$ \\
\hline Atopiás vagy gyulladásos bélbeteg apa & $12(25,5 \%)$ \\
\hline Atopiás vagy gyulladásos bélbeteg testvér & $16(45,7 \%)$ \\
\hline \multicolumn{2}{|l|}{ Perinatalis körülmények } \\
\hline Koraszülött & $4(8,5 \%)$ \\
\hline Terminusra született & $40(85,1 \%)$ \\
\hline Hüvelyi úton született & $35(74,5 \%)$ \\
\hline Császármetszéssel született & $12(25,5 \%)$ \\
\hline Min. 6 hónapos korig kizárólag anyatejjel & \\
\hline táplálkozott & $18(38,3 \%)$ \\
\hline Min. 6 hónapos korig normál- vagy AR-tápszert & \\
\hline kapott & $14(29,8 \%)$ \\
\hline Min. 6 hónapos korig HA- vagy HA-AR tápszert & \\
\hline kapott & $11(23,4 \%)$ \\
\hline Tejtermékek bevezetése 12 hónapos kor előtt & $22(46,8 \%)$ \\
\hline Tejtermékek bevezetése 12-24 hónapos kor között & $23(48,9 \%)$ \\
\hline Tejtermékek bevezetése 24 hónapos kor után & $2(4,3 \%)$ \\
\hline \multicolumn{2}{|l|}{ Tünetek } \\
\hline Gastrointestinalis & $40(85,1 \%)$ \\
\hline Légzőszervi & $27(57,4 \%)$ \\
\hline Bör & $30(63,8 \%)$ \\
\hline Idegrendszeri & $21(44,7 \%)$ \\
\hline \multicolumn{2}{|l|}{ Elvégzett diagnosztikai vizsgálatok } \\
\hline Pozitív Prick-teszt & $2(4,3 \%)$ \\
\hline Pozitív LTT & $8(17 \%)$ \\
\hline Kétes LTT & $3(8,5 \%)$ \\
\hline
\end{tabular}

LTT = lymphocytatranszformációs teszt reik körében atopia vagy gyulladásos bélbetegség, míg ebben a tekintetben a szülők körében alacsonyabb volt e betegségek előfordulási aránya (apa: 25,5\%, anya: $23,4 \%)$. A vizsgált populációban 4 gyermek volt koraszülött, 40-en terminusra születtek, 3 gyermek szülője nem válaszolt erre a kérdésre. A gyermekek nagy része (74,5\%) hüvelyi úton született, kisebb részük császármetszéssel jött világra. A résztvevők több mint fele $(61,7 \%)$ életének első fél évében anyatejes táplálást vagy hipoallergén tápszert kapott, valamint közel 50\%-uknál kerültek a tejtermékek bevezetésre 12 hónapos kor előtt. A kutatás résztvevői a leggyakrabban gastrointestinalis $(85,1 \%)$ tünetekről számoltak be, de a légzőszervi $(57,4 \%)$, a bőr$(63,8 \%)$ és idegrendszeri $(44,7 \%)$ szimptómák is nagy számban fordultak elö. A legtöbb esetben több szervrendszert érintő panaszokkal érkeztek szakrendelésünkre a gyermekek.

A Prick-teszt csupán 2 (4,3\%) gyermeknél adott pozitív eredményt tejre vonatkozóan. Három gyermeknél $(6,4 \%)$ nem végeztük el ezt a vizsgálatot. Mindkét gyermek, akinek pozitív lett a Prick-teszt-eredménye, fiú, és mindkettőjüknél jelentkeztek bőr- és légzőszervi tünetek, ezenfelül egyiküknél gastrointestinalis és idegrendszeri problémákról is beszámolt a szülő.

Az LTT-eredményeket vizsgálva 8 gyermeknél (17\%) kaptunk pozitív, 4-nél $(8,5 \%)$ pedig kétes eredményt. A kétes eredményú gyermekek körében a vizsgálat ismétlése indokolt, mivel azonban nagyon kis százalékban mutatott pozitivitást ez a módszer a mintában, nem végeztük el újra a mérést.

\section{Viselkedészavar, hiperaktivitás, alvászavar}

A vizsgálatban részt vevő 47 gyermekből ebben a részvizsgálatban 4 kisgyermeket $(8,5 \%)$ kizártunk $(n=43$; 58,1\% fiú, átlagéletkor: 7,88 év, SD: 4,02), mert koruknál fogva (3 év alatti, közösségbe nem járó gyermekek) a DSM-5 szerinti ADHD-tünetlistával kapcsolatos kérdéseket rájuk vonatkozóan nem lehetett kitölteni. Az első megjelenéskor 9 gyermek szülője (20,9\%) figyelemzavarra, 8 gyermek szülője $(18,6 \%)$ hiperaktivitásra panaszkodott. Azt, hogy gyermeke nyugtalanul alszik, az éjszaka folyamán többször felébred, 16 szülő (34\%) említette. A 3 hónapos eliminációs diétát követően arról számoltak be a vizsgált gyermekek szülei, hogy ezek a viselkedésbeli tünetek nagyrészt elmúltak. 12 gyermeknél $(27,9 \%)$ nyugodtabb viselkedést figyeltek meg napközben, és 15 gyermek szülője $(34,9 \%)$ számolt be kiegyensúlyozottabb alvásról a vizsgálat megkezdését követően 3 hónappal. Egy gyermeknél (2,3\%) nem hozott jelentős javulást alvásminőség tekintetében az eliminációs diéta. $\mathrm{Az}$ ADHD-tünetlista alapján kitöltött kérdéssor eredményeit tekintve objektívebb képet kaphatunk a pszichés eltérésekről. Gyermekeik viselkedésével kapcsolatosan a szülőkkel töltettük ki a DSM-5 ADHD-ra vonatkozó kérdéssorát, melynek kiértékelését követően azt tapasztaltuk, hogy több gyermeknél állnak fenn pszichés tünetek, 


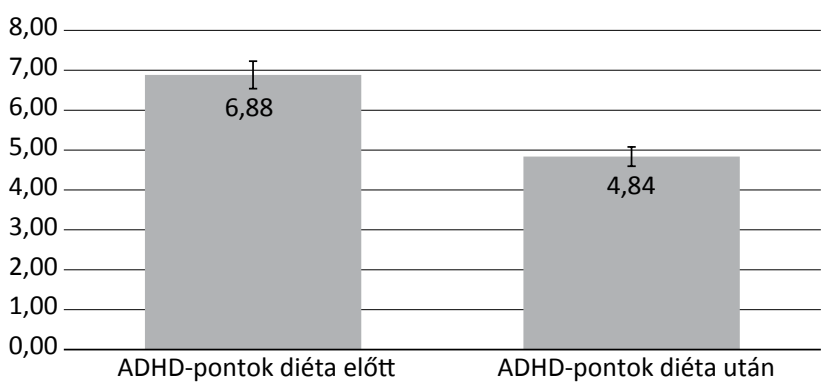

2. ábra $\quad$ ADHD-szerű tünetek jelentkezése az eliminációs diéta hatására $(\mathrm{n}=43 ; \mathrm{p}=0,001)$

ADHD = figyelemhiányos hiperaktivitási zavar

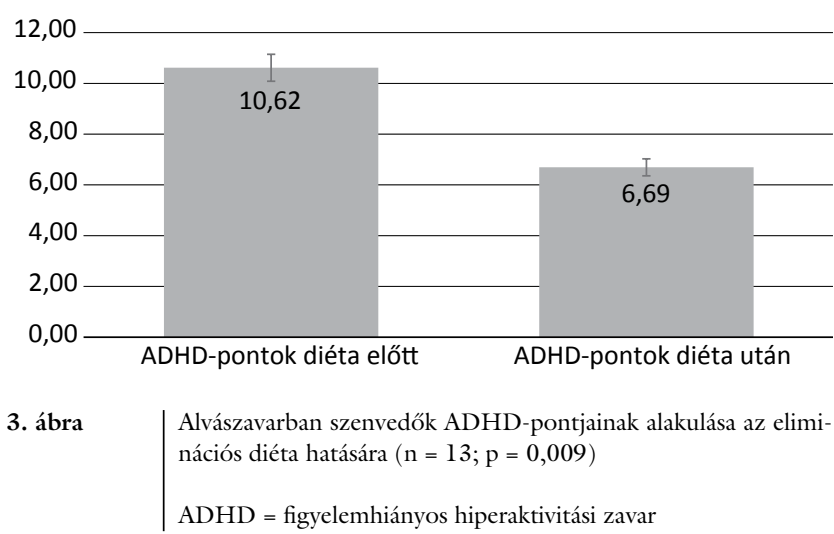

mint ahányan megemlítették a tünetek közt az első, gasztroenterológiai szakrendelésen való megjelenésükkor. A kérdéssor első 9 kérdését tekintve minimum 6 'igen' válasz esetén a figyelemzavaros, a 10-18. kérdéssel kapcsolatban minimum 6 igenlő válasz megléte esetén a hiperaktív kategóriába soroltuk a gyermekeket. Ez alapján 9 gyermek $(20,9 \%)$ került a figyelemzavaros, 10 $(23,3 \%)$ pedig a hiperaktív csoportba.

Összességében nézve a kérdőívek alapján számolt ADHD-pontokat, elmondhatjuk, hogy a diétát követően szignifikáns csökkenés figyelhető meg ezen a téren $(\mathrm{p}<0,001)$. Míg a diétát megelőzően az ADHD-pontok száma a teljes mintában átlagosan 6,88 (SD: 4,43) volt, addig a diétát követôen ez az érték 4,48 (SD: 3,69$)$ lett (2. ábra).

Megvizsgálva az alvászavarral érkezők ADHD-pontjait (10,62; SD: 4,23), szignifikáns csökkenést tapasztaltunk a diétát követően $(6,69 ; \mathrm{SD}: 4,59 ; \mathrm{p}=0,009)$ (3. ábra).

\section{Kortizol}

A vizsgálati csoportból 2 gyermek nyálkortizolszintjét nem tudtuk meghatározni, mivel a vizsgálathoz szükséges biológiai minta elégtelen mennyiségúnek bizonyult, így 45 gyermek reggeli és esti kortizolszintjét mértük ELISA-módszerrel. A 3. táblázat a mintavételezés időpontjait és az átkonvertált kortizolszinteket tartalmazza.

3. táblázat |Kortizol-mintavételi időontok és mérési eredmények

\begin{tabular}{lcr}
\hline & $\begin{array}{c}\text { Diéta elótt } \\
\text { (átlag } \pm \mathrm{SD} \text { ) }\end{array}$ & \multicolumn{1}{c}{$\begin{array}{c}\text { Diéta után } \\
\text { (átlag } \pm \mathrm{SD} \text { ) }\end{array}$} \\
\hline Reggeli mintavételi időpont $(\mathrm{h})$ & $07: 15 \pm 0: 54$ & $7: 34 \pm 1: 03$ \\
Reggeli kortizolszint nmol/1 & $15,46 \pm 5,54$ & $14,99 \pm 6,70$ \\
Esti mintavételi időpont $(\mathrm{h})$ & $19: 35 \pm 0: 50$ & $19: 16 \pm 1: 42$ \\
Esti kortizolszint nmol/1 & $5,44 \pm 2,63$ & $5,50 \pm 0,99$ \\
\hline
\end{tabular}

$\mathrm{SD}$ = standard deviáció

A diéta megkezdését megelőzően, illetve a 3 hónap múlva mért kortizolszintek között nem találtunk szignifikáns különbséget sem a reggeli (a diéta elótti kortizolszintátlag: 15,46 ; SD: 5,54 ; a diéta utáni kortizolszintátlag: 14,99; SD: 6,$70 ; p=0,64)$, sem az esti minták tekintetében (a diéta előtti kortizolszintátlag: 5,44; SD: 2,63; a diéta utáni kortizolszintátlag: 5,50; SD: 0,99; $\mathrm{p}=0,68)$. Mindkét esetben szignifikánsan csökkent a reggeli értékhez képest a kortizol szintje az esti mérés idejére (a diéta előtt $\mathrm{p}<0,001$ és a diéta után: $\mathrm{p}<0,001$ ) (4. ábra).

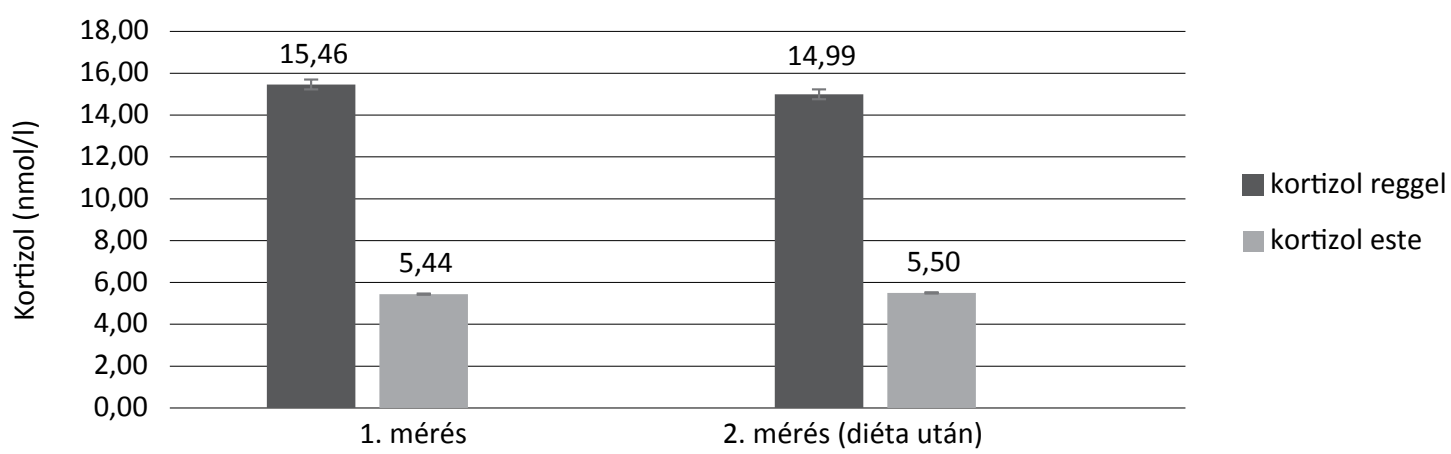

4. ábra $\mid$ A kortizolszintek alakulása a reggeli és esti mérések során diéta előtt és után 


\section{Megbeszélés}

Gyermekek körében a leggyakrabban előforduló táplálékallergia a tehéntejfehérje-allergia [22]. A Magyar Allergológiai Klinikai Immunológiai Társaság (MAKIT) által koordinált, Magyarország minden régiójára kiterjedő, multicentrikus felmérés szerint az ételallergének közül a tej a 2 . helyet foglalja el a gyakorisági sorrendben. $\mathrm{Az}$ említett tanulmányban kitérnek arra is, hogy ez az adat a nemzetközi irodalomban fellelhető megfigyelésekkel is összhangban van [4]. Egy hazai kutatócsoport feltételezése szerint az említett korcsoportban a betegség gyakoribb kialakulása a relatív nagy mennyiségü tejfogyasztással, illetve az immunrendszer éretlenségével magyarázható [23]. Magyarországon a bölcsődei és óvodai közétkeztetésben 10 élelmezési nap alatt 5 , illetve 4 liter tej biztosítandó a gyermekeknek, ami napi szinten 0,5 , illetve 0,4 liter tej elfogyasztását jelenti [24]. Mivel a betegség tünettana rendkívül színes, a diagnózis felállítása sokszor próbára teszi a tapasztalt orvosokat is [5, 25]. A British Society for Allergy and Clinical Immunology kutatói által megfogalmazottak alapján a tejfehérjeallergia azonnali és késleltetett reakciók formájában nyilvánulhat meg. Az IgE-mediált allergia azonnali tüneteket produkál (anafilaxia, akut urticaria, hányás, rhinitis, száraz köhögés, gégeödéma, zihálás, akut asztmás roham), míg a késleltetett tünetek a nem IgE-mediált allergia fennállását jelzik (atopiás dermatitis, krónikus hasmenés, véres széklet, krónikus hányás, vashiányos anaemia, súlyvesztés) $[1,5]$, de előfordulhat ezek kevert megjelenési formája is [26]. Az általunk vizsgált populációban a nem IgE-mediált allergiás betegek voltak túlnyomó többségben. Humánkutatásunk célja, hogy felmérjük, melyik a legalkalmasabb diagnosztikai módszer a tehéntejfehérjeallergia fennállásának alátámasztására, valamint hogy leírjuk, milyen organikus és esetlegesen pszichés eltérések jelentkezhetnek az említett allergiában, és ezekre milyen hatással van a tejfehérje-eliminációs diéta bevezetése. Hosszú távon célunk megfigyelni, hogy a tejfehérjementes diéta jótékony hatása hogyan monitorozható objektív paraméterek segítségével.

A diagnosztikai módszereket vizsgálva, tapasztalataink megfelelnek a nemzetközi és hazai szinten is elfogadott nézeteknek. A tehéntejfehérje-specifikus IgE-vizsgálat, a Prick-teszt és az LTT mint objektív vizsgálati módszer a diagnózis felállításához vagy elvetéséhez önmagában nem elegendő $[9,11,27]$. Greer és mtsai azt találták, hogy a családi anamnézisben szereplő atopia gyakori a tejfehérjeallergiás gyermekek körében [28]. Kutatásunk során mi is észleltük, hogy a szülők és a testvérek körében gyakran előfordul atopia vagy gyulladásos bélbetegség.

Kutatásunk erőssége a pszichés eltérések feltérképezésének kísérlete volt. Hasonló kutatással kapcsolatos közlemény sem a hazai, sem a nemzetközi szakirodalomban nem lelhető fel legjobb tudomásunk szerint. A vizsgált populációban nagy számban fordult elő tünetként hiperaktivitás, impulzivitás, figyelem- és alvászavar. A DSM-5
ADHD-tünetlistáját alapul véve elkészített kérdőív kitöltésével célunk volt objektívebb módszerrel is megismerni a gyermekek érintettségét ezen a területen. A vizsgált csoportban $(n=43)$ azt tapasztaltuk, hogy kevesebb szülő számolt be az első megjelenéskor a fent említett idegrendszeri tünetekről, mint azt a DSM-5 szerinti ADHD-kérdőívben jelezték. Kilenc szülő $(20,9 \%)$ jelezte, hogy gyermekénél problémát jelent a figyelem fenntartása, 8 pedig $(18,6 \%)$, hogy az átlagnál impulzívabb, hiperaktívabb a gyermek, valamint 16 szülő (34\%) említette, hogy gyermekénél alvászavart tapasztal éjszakánként. Összességében elmondható, hogy az ADHD-tünetlista alapján szerzett pontokat figyelembe véve, szignifikáns javulást értünk el az érintett gyermekek körében a 3 hónapos eliminációs diétával (a diéta előtti ADHD-pontok átlaga: 6,88 $\pm 4,43$; a diéta után: 4,48 \pm $3,69 ; \mathrm{p}=0,001)$. Hasonló eredményeket tapasztaltunk az alvászavart megemlítő gyermekek ADHD-pontjaival kapcsolatosan is, de a tünetek mérséklődése itt még látványosabb volt (a diéta elötti $\mathrm{ADHD}$-pontok átlaga: $10,62 \pm 4,23$; a diéta után: $6,69 \pm 4,59 ; \mathrm{p}=0,009)$.

$\mathrm{Az}$ ADHD jellegű tünetek fennállását terveztük bizonyítani a nyálkortizolszint-méréssel mint objektív diagnosztikai módszerrel. Több nemzetközi tanulmány számol be gyermekeknél alacsonyabb kortizolértékekről ADHD esetén [29, 30]. A nyálkortizolszint mérését gyakran alkalmazzák az akut és krónikus stressz kutatása céljából, akár gyermekpopuláción is, hiszen a vizsgálat noninvazív módon zajlik, kivitelezése egyszerü, olcsó, és nem szükséges a mintavételezéshez egészségügyi személyzet [31]. Vizsgálatunk során a kortizolszint a hiperaktív/figyelemhiányos gyermekek körében nem mutatott szignifikáns eltérést az ilyen jellegú tüneteket nem mutató gyerekek csoportjában mért eredményektől. Az eliminációs diéta előtti-utáni eredmények sem mutattak számottevő különbséget a teljes vizsgálati populációban. Egy következő betegcsoporton további vizsgálatokat tervezünk végezni más mediátorok (alfa-amiláz, szerotonin) mérésének hozzáadásával, hogy a fennálló viselkedésbeli eltérést objektív módon is alá tudjuk támasztani. Ezen részkutatás sikertelenségének egyik valószínűsíthető oka a nem protokoll szerinti mintavétel. A kortizolszint cirkadián ritmusát ismerve $[31,32]$ meghatározó jelentőségű az ébredés utáni azonnali mintavétel a mérés pontosságának érdekében, ezért a jövőben erre még inkább felhívjuk a résztvevők szüleinek figyelmét.

\section{Következtetés}

Kutatásunk eredményei alapján elmondhatjuk, hogy a tehéntejfehérje-allergiás gyermekeknél a pontos diagnózis felállításához nem elegendő a Prick-teszt vagy a lymphocytatranszformációs teszt elvégzése, ezek önmagukban nem támasztják alá a betegség fennállását, ugyanakkor negativitásuk nem zárja ki az allergia diagnózisát. Továbbra is az eliminációs diétát követő visszaterhelés a legbiztosabb módja a táplálékallergia diagnosztizálásá- 
nak. Tapasztalataink alapján biztosan állíthatjuk, hogy mind a klinikai tünetek, mind a pszichés eltérések terén látványos javulás érhető el a szigorú eliminációs diéta tartásával.

Anyagi támogatás: A közlemény a Richter Gedeon Talentum Alapítvány anyagi hozzájárulásával készült.

Szerzôi munkamegosztás: L.-E. D.: A kutatómunka levezetése, a minták vizsgálata, az eredmények értékelése, a közlemény megírása. E. V.: A betegek kiválasztása, minta- és adatgyüjtés, a közlemény megírása. F. K.: Az eredmények értékelése, a statisztikai számítások kivitelezése. P. V.: Irodalomkutatás. N. V., L. R.: A diagnosztikai tesztek kivitelezése. T.G.: A kutatómunka megtervezése, a betegek kiválasztása. A cikk végleges változatát valamennyi szerző elolvasta és jóváhagyta.

Érdekeltségek: A szerzőknek nincsenek érdekeltségei.

\section{Irodalom}

[1] Luyt D, Ball H, Makwana N, et al. BSACI guideline for the diagnoses and management of cow's milk allergy. Clin Exp Allergy 2014; 44: 642-672.

[2] Polgár M. (ed.) Adverse food allergies. [Adverz táplálékreakciók.] UCB Magyarország Kft., Budapest, 1997. [Hungarian]

[3] Polgár M. (ed.) Allergy in infants and children. [Allergia csecsemő- és gyermekkorban.] Springer Hungarica Kiadó, Budapest, 1996. [Hungarian]

[4] Sipka S, Gyimesi E. The laboratory diagnosis of food allergies. [Az ételallergiák laboratóriumi diagnosztikája.] Orv Hetil. 2007; 148: 299-302. [Hungarian]

[5] Caffarelli C, Baldi F, Bendandi B, et al. Cow's milk protein allergy in children: a practical guide. Ital J Pediatr. 2010; 36: 5.

[6] Høst A. Cow's milk protein allergy and intolerance in infancy. Some clinical, epidemiological and immunological aspects. Pediatr Allergy Immunol. 1994; 5(Suppl 5): 1-36.

[7] Endre L, Osváth P. Antigen-induced lymphoblast transformation in the diagnosis of cow's milk allergic diseases in infancy and early childhood. Acta Allergol. 1975; 30: 34-42.

[8] Chapman JA, Bernstein LI, Lee RE, et al. Food allergy: a practice parameter. Ann Allergy Asthma Immunol. 2006; 96(Suppl 2): S1-S68.

[9] Boyce JA, Assa'ad A, Burks AW, et al. Guidelines for the diagnosis and management of food allergy in the United States: report of the NIAID-sponsored expert panel. J Allergy Clin Immunol. 2010; 126 (Suppl 6): S1-S58.

[10] Sampson HA, Aceves S, Bock SA, et al. Food allergy: a practice parameter update - 2014. J Allergy Clin Immunol. 2014; 134: 1016-1025.e43.

[11] Tainio VM, Savilahti E. Value of immunologic tests in cow milk allergy. Allergy 1990; 45: 189-196.

[12] Nigg JT, Holton K. Restriction and elimination diets in ADHD treatment. Child Adolesc Psychiatr Clin N Am. 2014; 23: 937953.

[13] Kaplan BJ, McNicol J, Conte RA, et al. Dietary replacement in preschool-aged hyperactive boys. Pediatrics 1989; 83: 7-17.
[14] Madzhidova S, Sedrakyan L. The use of dietary interventions in pediatric patients. Pharmacy 2019; 7: 10.

[15] Oláh É. (ed.) Pediatric textbook I. [Gyermekgyógyászati kézikönyv I.] Medicina Könyvkiadó, Budapest, 2008. [Hungarian]

[16] Heinzerling L, Mari A, Bergmann KC, et al. The skin prick test - European standards. Clin Transl Allergy 2013; 3: 3.

[17] Michels N, Sioen I, De Vriendt T, et al. Children's morning and evening salivary cortisol: pattern, instruction compliance and sampling cofounders. Horm Res Pediatr. 2012; 77: 27-35.

[18] Hanrahn K, McCarthy AM, Kleiber C, et al. Strategies for salivary cortisol collection and analysis in research with children. Appl Nurs Res. 2006;19: 95-101.

[19] IBL, Hamburg. Instructions for use: Cortisol LIA. Available from: www.IBL-Hamburg.com (6/28/04). Retrieved on July 7 , 2004.

[20] Jay Clinical Services. Clinical analyte unit conversation. Available from: http://dwjay.tripod.com/conversion.html. Retrieved on July, 4, 2004 .

[21] Abrahám M, Nussbaum MD. (eds.) The pocket guide to the DSM-5 diagnostic exam. [A DSM-5 diagnosztikai vizsgálat zsebkönyve.] Oriold és Társai Kft., Budapest, 2013. [Hungarian]

[22] Spergel JM. Natural history of cow's milk allergy. J Allergy Clin Immunol. 2013; 131: 813-814.

[23] Barna M, Pálfi E, Horváth Z. Nutritional safety of food allergic consumers is our shared goal. [A táplálékallergiás fogyasztók táplálkozási biztonsága közös ügy.] Élelmiszervizsg Közl. 2009; 55: 83-104. [Hungarian]

[24] EMMI Regulations [37/2014. (IV. 30.) EMMI rendelet a közétkeztetésre vonatkozó táplálkozás-egészségügyi elő́rásokról.] Available from: https://net.jogtar.hu/jogszabaly?docid= al400037. emm [accessed: April 2, 2019]. [Hungarian]

[25] Vandenplas Y, De Greef E, Devreker T. Treatment of cow's milk protein allergy. Pediatr Gastroenterol Hepatol Nutr. 2014; 17: $1-5$.

[26] Koletzko S, Niggemann B, Arató A, et al. Diagnostic approach and management of cow's-milk protein allergy in infants and children: ESPGHAN GI Committee Practical Guidelines. J Pediatr Gastroenterol Nutr. 2012; 55: 221-229.

[27] Hoffman KM, Ho DG, Sampson HA. Evaluation of the usefulness of lymphocyte proliferation assays in the diagnosis of allergy to cow's milk. J Allergy Clin Immunol. 1997; 99: 360-366.

[28] Greer FR, Sicherer SH, Burks AW, et al. Effects of early nutritional interventions on the developement of atopic disease in infants and children: the role of maternal dietary restriction, breastfeeding, timing of introduction of complementary foods, and hydrolyzed formulas. Pediatrics 2008; 121: 183-191.

[29] Isaksson J, Nilsson KW, Nyberg F, et al. Cortisol levels in children with attention-deficit/hyperactivity disorder. J Psychiatr Res. 2012; 46: 1398-1405.

[30] Meguid N, Reda M, El Sheikh M, et al. Salivary cortisol levels in abused children with attention deficit hyperactivity disorder. J Psychiatry 2016; 19: 348.

[31] Kirshbaum C, Hellhammer DH. Salivary cortisol. In: Fink G. (ed.) Encyclopedia of stress. Academic Press, San Diego, CA, 2000; Vol 3, pp. 379-384.

[32] Kudielka BM, Kirschbaum C. Awakening cortisol responses are influenced by health status and awakening time but not by menstrual cycle phase. Psychoneuroendocrinology 2003; 28: 35-47.

(Lendvai-Emmert Dominika, e-mail: dominika.emmert@gmail.com)

A cikk a Creative Commons Attribution 4.0 International License (https://creativecommons.org/licenses/by/4.0/) feltételei szerint publikált Open Access közlemény, melynek szellemében a cikk bármilyen médiumban szabadon felhasználható, megosztható és újraközölhetö, feltéve, hogy az eredeti szerző és a közlés helye, illetve a CC License linkje és az esetlegesen végrehajtott módosítások feltüntetésre kerülnek. (SID_1) 